\title{
Adenovirus vectors from various serotypes induce distinct cytokine profiles
}

\author{
JE Teigler*, M lampietro, DH Barouch \\ From AIDS Vaccine 2012 \\ Boston, MA, USA. 9-12 September 2012
}

\section{Background}

Adenovirus (Ad) vectors from various serotypes which differ markedly in their basic biology are being pursued as candidate HIV vaccines. However, the innate immune responses elicited by different Ad vectors remain poorly characterized. We therefore evaluated cytokine responses to Ad vector stimulation both in vitro in human PBMC and in vivo following vaccination of rhesus monkeys.

\section{Methods}

Human PBMC were stimulated in vitro with $10^{3} \mathrm{vp} / \mathrm{cell}$ Ad5, Ad35, Ad26, Ad48, or Ad5/35 chimeric vectors. Rhesus monkeys were immunized with $3 \times 10^{10}$ vp Ad5, Ad35, Ad26, Ad48, or Ad5HVR48. Cytokines in culture supernatant and serum from vaccinated monkeys were measured by luminex assays and ELISA.

\section{Results}

Ad35 and Ad26 induced higher levels of antiviral and proinflammatory cytokines (e.g. IFN $\alpha 2$, IFN $\gamma$, IL-1 $\beta$ ) compared to Ad5 in human PBMC $(\mathrm{p}<0.01$, KruskalWallis test; Dunn's correction). Replacement of Ad5 fiber with that of Ad35 (Ad5f35) increased cytokine induction, while Ad35f5 displayed decreased stimulation, indicating the importance of fiber-receptor interactions for innate immune stimulation. Similarly, monkeys vaccinated with Ad35 or Ad26 also displayed markedly higher levels of antiviral and proinflammatory cytokines compared to Ad5 on day 1 post-vaccination ( $\mathrm{p}<0.05$, Mann-Whitney U test).

\section{Conclusion}

These data demonstrate that CD46-uilizing Ad35 and Ad26 vectors induce profoundly different innate

Division of Vaccine Research, Beth Israel Deaconess Medical Center, Boston, MA, USA

() Biomed Central

(C) 2012 Teigler et al; licensee BioMed Central Ltd. This is an Open Access article distributed under the terms of the Creative Commons Attribution License (http://creativecommons.org/licenses/by/2.0), which permits unrestricted use, distribution, and reproduction in any medium, provided the original work is properly cited. immune responses as compared to CAR-utilizing Ad5 vectors both in vitro and in vivo. These findings confirm that major biologic differences exist among Ad vectors and may help explain their different adaptive immune phenotypes.

Published: 13 September 2012

doi:10.1186/1742-4690-9-S2-015

Cite this article as: Teigler et al:: Adenovirus vectors from various serotypes induce distinct cytokine profiles. Retrovirology 2012 9(Suppl 2): 015 .

Submit your next manuscript to BioMed Central and take full advantage of:

- Convenient online submission

- Thorough peer review

- No space constraints or color figure charges

- Immediate publication on acceptance

- Inclusion in PubMed, CAS, Scopus and Google Scholar

- Research which is freely available for redistribution 